\title{
PENGARUH SUBSTITUSI PAKAN KOMERSIL OLEH TEPUNG BUNGKIL INTI SAWIT TERHADAP NILAI ENERGI METABOLIS DAN KECERNAAN RANSUM AYAM KAMPUNG
}

\section{THE INFLUENCE OF COMMERCIAL FEED SUBSTITUTION FOR CAKE FLOUR BY PALM KERNEL OF ENERGY RATION DIGESTIBILITY AND METABOLIS FREE-RANGE CHICKEN}

\author{
AA Mulyana1, D Sudrajat'1a, dan Jatmiko \\ ${ }^{1}$ Program Studi Peternakan, Fakultas Pertanian, Universitas Djuanda Bogor Jl. Tol Ciawi No. 1, Kotak Pos \\ 35 Ciawi, Bogor 16720. \\ a Korespondensi: Deden Sudrajat, E-mail: deden.sudrajat@unida.ac.id \\ (Diterima: 28-12-2016; Ditelaah: 28-12-2016; Disetujui: 06-02-2017)
}

\begin{abstract}
Palm kernel for cake which is used as animal feed, potentially replacing big feed ingredients in commercial rations. This research was conducted to evaluate the energy metabolis rations contain palm kernel for cake on a free-range chicken. Draft research using randomized complete design with the use of as many as 16 free-range chickens randomly arranged into 4 treatments and 4 replicates. The treatment used is $\mathrm{R} 0=$ feeding a commercial without the addition of palm kernel for cake; $\mathrm{R} 1$ = feeding a commercial with the addition of $10 \%$ for cake palm kernel; R2 = feeding a commercial with the addition of $15 \%$ for cake palm kernel; R3 = feeding a commercial with the addition of $20 \%$ for cake palm kernel. The observed variables are composed of energy and digestibility of metabolis free-range chicken rations using indicators of $\mathrm{Cr} 203$. The results of research using the method of indicator showing that palm kernel for cake flour has no effect on the real energy ration digestibility and metabolis. However, on a rough fat digestibility showed that the addition of palm kernel for cake flour is very influential real $(P<0,01)$. Keywords: energy metabolism, flour for cake palm kernel, free-range chicken.
\end{abstract}

\begin{abstract}
ABSTRAK
Bungkil inti sawit yang digunakan sebagai pakan ternak, berpotensi besar menggantikan sebagian bahan pakan pada ransum komersial. Penelitian ini dilakukan untuk mengevaluasi energi metabolis ransum mengandung bungkil inti sawit pada ayam kampung. Rancangan penelitian menggunakan rancangan acak lengkap dengan menggunakan sebanyak 16 ekor ayam kampung disusun secara acak menjadi 4 perlakuan dan 4 ulangan. Perlakuan yang digunakan adalah $\mathrm{R} 0=$ pemberian pakan komersil tanpa penambahan bungkil inti sawit; R1= pemberian pakan komersil dengan penambahan 10\% bungkil inti sawit; R2= Pemberian pakan komersil dengan penambahan 15\% bungkil inti sawit; R3= pemberian pakan komersil dengan penambahan $20 \%$ bungkil inti sawit. Peubah yang diamati terdiri dari energi metabolis dan kecernaan ransum ayam kampung dengan menggunakan metode indikator $\mathrm{Cr}_{2} \mathrm{O}_{3}$. Hasil penelitian menggunakan metode indikator menunjukkan bahwa tepung bungkil inti sawit tidak berpengaruh nyata pada energi metabolis dan kecernaan ransum. Namun, pada kecernaan lemak kasar menunjukkan bahwa penambahan tepung bungkil inti sawit sangat berpengaruh nyata $(\mathrm{P}<0,01)$.
\end{abstract}

Kata kunci: ayam kampung, energi metabolis, tepung bungkil inti sawit. 
Mulyana AA, D Sudrajat, dan Jatmiko. 2017. Pengaruh substitusi pakan komersil oleh tepung bungkil inti sawit terhadap nilai energi metabolis dan kecernaan ransum ayam kampung. Jurnal Pertanian 8(1): 1-6.

\section{PENDAHULUAN}

Ayam kampung adalah ayam lokal yang sudah dikenal lama dan dipelihara oleh masyarakat Indonesia. Penampilan dan penyebaran ayam kampung sangat beragam baik di kota maupun desa. Konsumsi ayam kampung di Indonesia meningkat dari tahun ke tahun yaitu dari 1,29 juta ton meningkat menjadi 1,52 juta ton pada tahun 2011 (Aman 2011). Usaha peternakan ayam lokal perlu dikembangkan dengan menerapkan teknologi yang mampu meningkatkan produktivitas dan pendapatan peternak. Berbagai rumpun ayam lokal telah diidentifikasi dan teknologi budi daya untuk meningkatkan produksinya telah tersedia (Nataamijaya 2010).

Produktivitas suatu ternak berbanding lurus dengan tingkat konsumsi nutrien, namun sekarang ini produktivitas ayam kampung termasuk rendah dari sisi pemberian pakan. Hal ini disebabkan salah satunya oleh pemberian pakan yang belum memperhitungkan kebutuhan zat-zat makanan untuk berbagai tingkat produksi. Kurangnya informasi cukup mengenai kebutuhan nutrisi untuk ayam kampung sehingga pemberian pakan masih mengandalkan pakan komersil. Penggunaan pakan alternatif non konvesional seperti penambahan tepung bungkil inti sawit pada pakan komersil ayam kampung diperlukan dalam rangka membantu produktivitas ayam kampung.

Bungkil inti sawit memiliki kandungan nutrisi cukup tinggi. Selain itu, ketersediaannya di Indonesia cukup melimpah dan harganya cukup bersaing. Bungkil inti sawit dapat digunakan untuk memenuhi energi dan protein (Satyawibawa 2000). Penggunaan bungkil inti sawit sebagai bahan penyusun ransum unggas sangat potensial dengan kandungan nutrisi yang tinggi, tetapi ada hal yang membatasi penggunaan bungkil inti sawit pada ransum unggas yaitu kandungan serat kasar yang tinggi, bungkil inti sawit mempunyai kandungan protein yang rendah tetapi berkualitas baik. Ternak yang mendapatkan campuran bungkil inti sawit akan mendapatkan lemak yang berkualitas baik (Sinurat et al.2009). Penelitian ini bertujuan untuk mengetahui kandungan energi metabolis dan kecernaan pada ayam kampung yang diberi ransum komersil dengan penambahan bungkil inti sawit.

\section{MATERI DAN METODE}

\section{Materi}

\section{Bahan dan Ternak}

Bahan yang digunakan dalam penelitian ini adalah ayam kampung berjumlah 160 ekor yang berumur satu hari, pemeliharan selama 12 minggu menggunakan ransum stater broiler yang diberikan dalam bentuk mesh yang mengandung $0 \%, 10 \%, 15 \%$, dan $20 \%$ tepung bungkil inti sawit. Pakan yang diberlkan berasal dari pakan komersial untuk ayam pedaging dari PT Sinta BR-21 E yang mengandung kadar air $12 \%$, protein kasar 20-22 \%, lemak kasar 4-8\%, serat kasar maks $4 \%$, abu maks $8 \%$, kalsium $0,9-1,2 \%$, fosfor 0,7-1,0 \% serta mengandung coccidiostat dan antibiotika. Bahan pakan yang digunakan dalam penyusunan ransum adalah jagung, dedak, CGM jagung, pollard, tepung daging dan tulang, bungkil kedelai, minyak kalsium fosfat, kalsium karbonat, natrium klorida, asam amino, vitamin, trace mineral, dan antioksidan.

Tepung bungkil inti sawit diperoleh dari pabrik Indofeed yang dijual di pasar pakan berupa butiran-butiran kecil kemudian digiling menjadi tepung dan disaring sehingga menjadi serbuk halus. Ayam yang digunakan pada saat uji adalah ayam kampung, dengan jenis kelamin jantan. Ayam yang digunakan adalah ayam kampung jantan berumur 84 hari dengan rata-rata bobot badan ayam kampung 762,85 \pm gram. Pakan yang 
digunakan selama penelitian menggunakan pakan komersil (Sinta dalam bentuk mash). Kandungan Nutrien pakan ayam kampung starter dan tepung bungkil inti sawit yang digunakan selama penelitian, hasil uji proksimat di lakukan di Laboratorium Terpadu Intitut Pertanian Bogor yang dapat dilihat pada Tabel 1.

Tabel 1 Hasil uji analisis proksimat pakan komersil dan tepung bungkil inti sawit

\begin{tabular}{|c|c|c|c|c|c|}
\hline \multirow{2}{*}{ Jenis sample } & Kadar air & $\mathrm{Abu}$ & Lemak & Protein & Serat Kasar \\
\hline & & &...$\% \ldots$. & 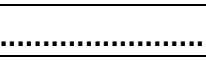 & . \\
\hline Sinta BR-12 E & 10,85 & 6,02 & 8,01 & 18,20 & 2,53 \\
\hline Tepung BIS & 5,87 & 6,16 & 12,84 & 13,14 & 11,88 \\
\hline
\end{tabular}

Sumber: Laboratorium Terpadu IPB (2015)

\section{Kandang dan Peralatan}

Kandang yang digunakan dalam penelitian ini adalah kandang individu atau kandang baterai supaya mudah dalam proses penampungan ekskreta ayam. Kandang sebanyak 20 petak dengan ukuran tinggi $40 \mathrm{~cm}$, lebar $18 \mathrm{~cm}$, dan panjang masing-masing $60 \mathrm{~cm}$ dimana setiap petak diisi 1 ekor ayam dan masingmasing petak dilengkapi dengan tempat pakan, tempat minum, wadah untuk menampung ekskreta dan penerangan lampu pijar, timbangan yang digunakan untuk menimbang ayam dan ekskreta ayam yang diteliti serta peralatan prosesing ayam meliputi: timbangan analitik, plastik untuk menampung ekskreta, dan sendok.

\section{Metode}

\section{Rancangan Percobaan dan Analisis Data}

Penelitian ini menggunakan Rancangan Acak Lengkap (RAL). Masing-masing terdiri dari 4 perlakuan dan 5 ulangan. Adapun perlakuan yang digunakan yaitu:

$\mathrm{R} 0=$ Pemberian pakan komersil tanpa penambahan bungkil inti sawit

R1 = Pemberian pakan komersil dengan penambahan $10 \%$ bungkil inti sawit

R2 = Pemberian pakan komersil dengan penambahan $15 \%$ bungkil inti sawit

$\mathrm{R} 3$ = Pemberian pakan komersil dengan penambahan $20 \%$ bungkil inti sawit

Model matematika yang digunakan menurut Mattjik dan Sumertajaya (2006) ialah sebagai berikut.
$Y_{\mathrm{ij}}=\mu+\tau_{\mathrm{i}}+\varepsilon_{\mathrm{ij}}$

Keterangan: $Y_{\mathrm{ij}}=$ variabel respons dari perlakuan ke-i dan ulangan ke-j; $\mu=$ pengaruh umum dan Rataan umum; $\tau_{\mathrm{i}}=$ galat percobaan pada perlakuan ke-i dan ulangan ke-j; $\alpha \mathrm{i}=$ pengaruh perlakuan; $\varepsilon \mathrm{ij} \mathrm{k}=$ galat.

Data yang diperoleh dianalisis dengan ANOVA dan apabila hasilnya berbeda nyata diuji dengan uji LSD dengan selang kepercayaan 95\%. Pengolahan data di analisis menggunakan program SPSS16.0

\section{Pelaksanaan Penelitian}

Adapun tahapan pelaksanaan penelitian yang dilakukan yaitu menyiapkan kandang individu dengan ukuran panjang, lebar dan tinggi masing-masing 60 x 18 x $40 \mathrm{~cm}$ yang dilengkapi dengan tempat pakan dan minum serta bak tempat penampung ekskreta yang dibawahnya dilapisi lembaran plastik. Berikut beberapa tahap dalam prosedur percobaan yaitu antara lain:

a. menimbang ayam dan memasukkan kedalam kandang sesuai dengan perlakuan;

b. ayam dipuasakan selama 1 hari setelah itu ayam di beri pakan secara cekok dan dicatat konsumsi perekor;

c. pada hari ke-2 lembaran plastik diganti yang baru pe rhari dan mulai pengamatan;

d. ekskreta ditampung dan dikumpulkan selama 1 hari, ditimbang dan dikeringkan di dalam oven dan ditimbang lagi setelah kering;

e. diambil sampel ekskreta masing-masing individu sebanyak yang diperlukan untuk analisis kimia, demikian juga sampel dari pakan 2perlakuan; 
$4 \quad$ Mulyana et al.

f. analisis kimia meliputi sampel pakan perlakuan dan ekskreta dianalisa bahan kering dan gross energi;

g. menghitung nilai energi metabolis kadar $\mathrm{Cr}_{2} \mathrm{O}_{3}$ ransum feses.

\section{Peubah yang Diamati}

Terdapat beberapa peubah yang diamati penelitian ini antara lain sebagai berikut.

\section{Energi Metabolis Ransum Metode Indikator}

Energi metabolis ransum metode indikator diambil dari Amrullah (2009) yakni sebagai berikut.

$\mathrm{EMr}=\mathrm{EBr}-$ koefisien eksreta $(\mathrm{EBe})$

Koefisien ekskreta $(\mathrm{Ke})=100 \%$ - (1 Indikator ekskreta $\times 100 \%)$

Indikator ransum

\section{Kencernaan Bahan Kering Metode Indikator}

Kecernaan bahan kering metode indikator ini dapat dilihat pada rumus di bawah sebagai berikut.

$\mathrm{KCBK}=\left(1-\frac{\mathrm{BK} \text { Feses }}{\text { BK Ransum }} \times \frac{\mathrm{Cr}_{2} \mathrm{O}_{3} \text { Pakan }}{\mathrm{Cr}_{2} \mathrm{O}_{3} \text { Feses }}\right) \times 100 \%$

\section{Kencernaan Lemak Kasar Metode Indikator}

Kecernaan lemak kasar metode indiaktor ini dapat dilihat pada rumus di bawah sebagai berikut.

$\mathrm{KCLK}=\left(1-\frac{\text { LK Feses }}{\text { LK Ransum }} \times \frac{\mathrm{Cr}_{2} \mathrm{O}_{3} \text { Pakan }}{\mathrm{Cr}_{2} \mathrm{O}_{3} \text { Feses }}\right) \times 100 \%$
Substitusi pakan komersil bungkil inti sawit

\section{HASIL DAN PEMBAHASAN}

\section{Energi Metabolis Ransum}

Energi metabolis adalah perbedaan antara kandungan energi bruto pakan atau ransum dengan energi bruto yang dikeluarkan melalui ekskreta (Sibbald 1980). Energi metabolis diperoleh dari pengurangan antara energi yang terkandung pada pakan yang dikonsumsi oleh unggas dikurangi dengan energi yang terkandung di dalam ekskreta. Energi metabolis ransum dengan metode indicator terdapat pada Tabel 2 .

Rataan nilai energi metabolis dengan metode indikator berkisar 2153,5 - 3330,5 nilai energi metabolis berturut-turut yang tertinggi diperoleh ransum perlakuan (R2), (R1), (R0), dan (R3). Hasil analisis menunjukan bahwa tepung bungkil inti sawit berpengaruh nyata $(\mathrm{P}<0,05)$ pada energi metabolis yang menggunakan metode indikator karena hasilnya menunjukan pengaruh yang signifikan dan terlihat dari adanya nilai dan huruf yang berbeda dalam satu kolom pada Tabel 2. Nilai energi metabolis ransum pada penelitian ini tidak berbeda jauh dengan hasil penelitian Sembiring (2009) yaitu energi metabolis ransum bungkil inti sawit yang tidak difermentasi dan yang difermentasi pada ayam adalah berturut-turut sebesar 2.260 $\mathrm{kkal} / \mathrm{kg}$ dan $2.1565 \mathrm{kkal} / \mathrm{kg}$.

Tabel 2 Energi metabolis ransum dengan metode indikator

\begin{tabular}{lrrr}
\hline \multicolumn{1}{c}{ Perlakuan } & EB Ransum $(\mathrm{kkal} / \mathrm{kg})$ & EB Ekskreta $(\mathrm{kkal} / \mathrm{kg})$ & \multicolumn{1}{c}{ EMn $(\mathrm{kkal} / \mathrm{kg})$} \\
\hline R0 & 4.099 & $3.477 \pm 81,41 \mathrm{a}$ & $2.559 \pm 249,68$ \\
R1 & 4.181 & $3.492 \pm 48,52 \mathrm{a}$ & $2.615 \pm 387,06$ \\
R2 & 4.268 & $3.365 \pm 127,58 \mathrm{a}$ & $3.330 \pm 267,12$ \\
R3 & 4.246 & $3.626 \pm 19,38 \mathrm{~b}$ & $2.153 \pm 1043,87$ \\
\hline
\end{tabular}

Keterangan $: \mathrm{EMn}=$ energi metabolis terkoreksi nitrogen. $\mathrm{EB}=$ energi bruto. $(\mathrm{kkal} / \mathrm{kg})=$ kilokalori per kilogram, Hasil analisa Labratorium PAU IPB (2015). R0 : 100\% ransum basal, R1 : 90\% ransum basal + $10 \%$ tepung bungkil inti sawit, R2 : 85\% ransum basal $+15 \%$ tepung bungkil inti sawit, R3 : 80\% ransum basal $+20 \%$ tepung bungkil inti sawit. Supercript nilai dengan huruf yang berbeda dalam satu kolom menunjukan perbedaan yang nyata $\mathrm{P}(<0,05)$ dan huruf yang sama menunjukkan perbedaan yang tidak nyata. 


\section{Kecernaan Bahan Kering}

Kencernaan BK dapat dipengaruhi oleh kandungan zat-zat makanan dalam ransum dan jumlah yang dikonsumsinya, mengatur kencernaan dibutuhkan teknik khusus. Perbedaan tingkat kecernaan bahan kering (KCBK) dengan beberapa perlakuan yang berbeda dipengaruhi oleh jenis dan kandungan pakan yang diberikan. Selain itu perbedaan tingkat kecernaan ayam ini juga dpengaruhi oleh beberapa faktor antara lain jumlah dan jenis pakan yang dikonsumsi, kemampuan ternak dalam mencerna bahan pakan, kondisi ternak dan lingkungan (Nelwida 2009). Kecernaan bahan kering metode indikator dapat dilihat pada Tabel 3.

Tabel 3 Kecernaan bahan kering ransum ayam kampung

\begin{tabular}{lrrrr}
\hline Perlakuan & EM Ransum (\%) & BK Ransum (\%) & BK Feses (\%) & KCBK (\%) \\
\hline R0 & 2,150 & 89,15 & $22,96 \pm 1,64$ & $50,72 \pm 3,39$ \\
R1 & 2,214 & 89,89 & $23,66 \pm 1,41$ & $38,10 \pm 25,5$ \\
R2 & 2,830 & 90,13 & $24,70 \pm 0,28$ & $38,05 \pm 4,21$ \\
R3 & 1,837 & 90,36 & $25,78 \pm 1,56$ & $47,12 \pm 9,43$ \\
\hline
\end{tabular}

Keterangan: BK adalah berat kering. R0 : 100\% ransum basal, R1 : 90\% ransum basal $+10 \%$ tepung bungkil inti sawit, R2 : 85\% ransum basal $+15 \%$ tepung bungkil inti sawit, R3 : 80\% ransum basal +20 $\%$ tepung bungkil inti sawit Supercript nilai dengan huruf yang berbeda dalam satu kolom menunjukan perbedaan yang nyata $\mathrm{P}(<0,05)$ dan huruf yang sama menunjukkan perbedaan yang tidak nyata.

Hasil analisis ragam menunjukan bahwa tepung bungkil inti sawit tidak berpengaruh $(\mathrm{P}>0,05)$ pada kencernaan bahan kering ransum. Berdasarkan penelitian yang dilakukan diperoleh hasil bahwa rataan tingkat kecernaan bahan kering (KCBK) ransum yang mengandung bungkil inti sawit berkisar 38,05 - 47,12\% berturut-turut yang tertinggi diperoleh ransum perlakuan (R3), (R1) dan (R2). Hasil kencernaan bahan kering pada penelitian ini cenderung lebih kecil jika dibandingkan dengan kencernaan bahan kering ayam broiler yang diberi ransum bungkil inti sawit fermentasi pada penelitian (Sari dan Purwadaria 2004) yakni berkisar antara 40,0 - 62,1\% pada inkubasi hari ke-4.

\section{Kecernaan Lemak Kasar}

Lemak kasar merupakan salah satu penyusun bahan organik suatu bahan pakan, sehingga naiknya kecernaan bahan organik akan berbanding lurus dengan kenaikan kecernaan lemak kasarnya. Kandungan lemak yang tinggi juga menyebabkan konsumsi lemak menjadi tinggi. Menurut Djulardi et al. (2006), pencernaan lemak memerlukan garam-garam empedu yang berfungsi untuk mengemulsikan lemak dalam lekukan duodenum. Lemak yang berbentuk emulsi dipecah oleh enzim lipase dari pankreas menjadi asam lemak dan gliserol sebagai hasil akhir pencernaan lemak. Kecernaan lemak kasar dengan metode indikator dapat dilihat pada Tabel 4.

Tabel 4 Kecernaan lemak kasar (LK) ransum ayam kampung

\begin{tabular}{|c|c|c|c|}
\hline Perlakuan & LK Ransum (\%) & LK Feses (\%) & KCLK (\%) \\
\hline R0 & 8,01 & $1,55 \pm 0,74 \mathrm{~b}$ & $63,00 \pm 2,03 a$ \\
\hline R1 & 9,43 & $1,42 \pm 0,18 a b$ & $70,65 \pm 3,70 b$ \\
\hline R2 & 9,66 & $1,26 \pm 0,13 a$ & $70,47 \pm 2,80 b$ \\
\hline R3 & 9,89 & $1,32 \pm 0,48 a$ & $76,50 \pm 3,28 c$ \\
\hline
\end{tabular}

Keterangan: LK adalah berat kasar. R0 $=100 \%$ ransum basal, R1 $=90 \%$ ransum basal $+10 \%$ tepung bungkil inti sawit, R2 $=85 \%$ ransum basal $+15 \% \%$ tepung bungkil inti sawit, R3 $=80 \%$ ransum basal + $20 \%$ tepung bungkil inti sawit Supercript nilai dengan huruf yang berbeda dalam satu kolom menunjukan perbedaan yang nyata $\mathrm{P}(<0,05)$ dan huruf yang sama menunjukkan perbedaan yang tidak nyata.

Berdasarkan penelitian yang dilakukan diperoleh hasil bahwa rataan tingkat kecernaan bahan lemak kasar (KCLK) ransum yang mengandung bungkil inti sawit berkisar $70,65-76,50 \%$ berturut-turut yang tertinggi diperoleh ransum perlakuan (R3), (R1), dan 
(R2). Hasil analisis ragam menunjukan bahwa tepung bungkil inti sawit sangat berpengaruh nyata $(\mathrm{P}<0,01)$ meningkatkan kencernaan lemak kasar ransum (Tabel 4). Tingkat kecernaan lemak kasar pada penelitian ini lebih besar dengan kencernaan lemak kasar ransum yang diberi bungkil inti sawit hasil penelitian Sukaryana et al. (2011) pada ayam broiler yakni sebesar 65,6\%, dengan menggunakan metode indicator lignin.

\section{KESIMPULAN DAN IMPLIKASI}

Pemberian tepung bungkil inti sawit sampai $15 \%$ tidak berpengaruh pada energi metabolis ransum dan kencernaan bahan kering. Pemberian bungkil inti sawit sampai $15 \%$ meningkatkan kecernaan lemak. Substitusi ransum komersil dengan BIS dapat diberikan pada ayam kampung.

\section{DAFTAR PUSTAKA}

Aman Y. 2011. Ayam kampung unggul. Penerbit Penebar Swadaya, Jakarta.

Amrullah IK. 2006. Nutrisi ayam broiler, lembaga satu gumung budi, KPP Baranang Siang Bogor.

Djulardi A, H Muis, dan SA Latif. 2006. Nutrisi aneka ternak dan satwa harapan. Cetakan Pertama. Andalas University Press, Padang.

Hartadi, H Reksohadiprodjo, dan Tilman. 1991. Ilmu makanan ternak dasar. Cetakan Kelima. Gajah Mada University Press, Yogyakarta.

Nataamijaya AG. 2010. Pengembangan potensi ayam lokal untuk menunjang peningkatan kesejahteraan petani. Jurnal Litbang Pertanian. Volume 29 Nomor 4, 131-138.

Nelwida. 2009. Efek penggantian jagung dengan biji alpukat yang direndam air panas dalam ransum terhadap retensi bahan kering, bahan organik dan protein kasar pada ayam broiler. Jurnal Ilmiah Ilmu-Ilmu Peternakan. Volume 12 Nomor 1, $50-56$.

Mattjik AA dan IM Sumertajaya. 2006. Perancangan percobaan dengan aplikasi SAS dan MINITAB, Jilid I. IPB-Press, Bogor.

Sari L dan T Purwadaria. 2004. Evaluate the Effect of Mutans Aspergillus Niger to the Nutritive Value of Fermentation at Coconut Meal and Karnel Palm Meal. Biodiversitas, Journal of Biological Diversity. Volume 5 Number 2, 48-51, doi:10.13057/biodiv/d050202.

Satyawibawa I dan YE Widyastuti. 2000. Kelapa sawit usaha budidaya pemanfaatan hasil dan aspek pemasaran. Penebar Swadaya, Jakarta.

Sembiring P. 2009. Peningkatan kecernaan protein dan energi bungkil inti sawit fermentasi pada ayam broiler (increased protein and energi metabolism digestibility by fermented palm kernel meal in broiler). Seminar Nasional Teknologi Peternakan Dan Veteriner, 626-32.

Sibbald IR. 1980. Metabolic plus endogenus energy and nitrogen losses of adult cockerels: the correction used in bioassay for true metabolizble energy. Internasional Develompment Research Center, Canada.

Sinurat AP, T Purwadaria, T Pasaribu, P Ketaren, H Hamid, Emmi, E Frederick, Udjianto, dan Haryono. 2009. Proses pengolahan bungkil inti sawit dan evaluasi biologis pada ayam. Laporan Hasil Penelitian TA 2008. Balai Penelitian Ternak, Bogor.

Sukaryana Y, E Supriyatna, U Atmomarsono, dan VD Yunianto. 2011. Peningkatan nilai kecernaan protein kasar dan lemak kasar produk fermentasi campuran bungkil inti sawit dan dedak padi pada broiler. JITP. Volume 1, 167-72. 